\title{
Determinant Factors of The Chrysantemum Consumers' Willingness to Pay: Case of Pasopati Cultivar
}

\author{
Puspita Dewi Hidayaningtyas ${ }^{1}$, Irham ${ }^{1}$, Arini Wahyu Utami ${ }^{1}$ \\ 1Department of Agricultural Socioeconomics, Faculty of Agriculture, Universitas \\ Gadjah Mada \\ puspitadewi95@mail.ugm.ac.id
}

Submitted : 1 November 2020 ; Revised : 4 March 2021 ; Accepted : 7 June 2021

\begin{abstract}
This study aims to: (1) determine the characteristics of chrysanthemum consumers in three cities in Java, namely Yogyakarta, Semarang and Surakarta, (2) compare the willingness to pay (WTP) of chrysanthemum consumers, especially Pasopaticultivar in the three cities, (3) analyze the determinant factors of the chrysanthemum consumers' WTP. There was a total of 120 respondents participated in this study, constituting 40 respondents in each city selected by using accidental sampling. The consumers' WTP was assessed using the contingent valuation method, and its determinant factor was analyzed using multiple regression. The results showed that the majority of chrysanthemum consumers in the three cities were 1725 years old, female, having a bachelor degree, owning a job, single and having no dependent family. The value of wilingness to pay from the three cities showed higher results than the market price at IDR 30,000. The highest WTP value was in Semarang City and the lowest WTP value was in Yogyakarta City. Based on the results of the regression, the determinants influencing the value of WTP differed in each city, but the income was a significant determinant in all cities. The value of WTP on chrysanthemum Pasopati cultivar can be used as a reference to set the selling price of chrysanthemum flowers. Chrysanthemum such as Pasopati cultivar in Indonesia, needs to be developed more by considering the willingness of consumers to pay.
\end{abstract}

Keywords : Chrysanthemum, Contingent Valuation Method, Pasopati Cultivar, Willingness to Pay

How to cite : Hidayaningtyas, P.D., Irham, and Utami, A.W. 2021. Determinant Factors of The Chrysantemum Consumers' Willingness to Pay : Case of Pasopati Cultivar. Agro Ekonomi $32(1), x x-x x$

\section{INTRODUCTION}

Floriculture has become an important industry in several countries along with the development of its functions (Briercliffe, 2017; Datta, 2018). Cut flowers that were used as a ritual complement are now also used for various needs and also as gifts (Short et al., 2017). One of the cut flower plants that have high economic value is the chrysanthemum. Chrysanthemum is a flower originating from China and developed in Indonesia since 1940 (Pusat Data dan Informasi Kementerian Pertanian, 2014). This flower is also used as a symbol of the Japanese emperor. 
Agro Ekonomi Vol.32/Issue.1, June 2021

Chrysanthemum flowers in Indonesia are one of the many flowers produced by farmers in various regions. The regions well-known as chrysanthemum producer include South Sumatra, Lampung, West Java, Central Java, Special Region of Yogyakarta, East Java, Bali, and North Sulawesi. According to BPS (2019), Indonesia's chrysanthemum production increased by 7.49 million stalks from 2017 to 2018. This coincided with the increase in demand for chrysanthemum flowers. Central Java Province is the third largest chrysanthemum producer in Indonesia, while Yogyakarta Special Region is the seventh biggest and fourth largest chrysanthemum producer in Java (BPS, 2018). This makes Java Island a potential chrysanthemum producer in Indonesia.

Indonesian ornamental plant research center (Balithi) began to breed several new cultivar of chrysanthemum since 1998. Until now, about 70 cultivars have been successfully bred. The advantages of this new cultivar include unique flowering, resistant to pests and adaptive to tropical weather. One of the cultivars that were bred by balithi was Pasopati. It was introduced in 2010, having a blooming period of 14-16 days and can adapt well at an altitude of 7001200 meters above sea level (Badan Litbang Pertanian, 2016). The development of new cultivar should be done because of growing number of consumer demands and preferences. In addition, the demand of the flower industry for unique flower attributes such as color, shape and durability of flowers becomes a challenge in cut flower marketing (Datta, 2018).
Many factors influence consumers in buying ornamental plants. Social demographic factors such as income, age, education and also the availability of flowers play an important role in the decision to purchase flowers made by consumers (Yue and Hall, 2010). Studies emphasized the product's price as an important attribute because price is essential in any economic transaction and expected to strongly impact consumer decision (Rombach et al., 2018). Several previous studies done by (Yue, 2008; Rombach et al., 2018) show that methods and location of purchasing flower influence the WTP value. This study aimed to determine how much the value of WTP consumers for chrysanthemum flowers in Pasopati cultivar in three cities namely Yogyakarta, Semarang and Surakarta. This study also compared the factors influencing the amount of WTP in those cities to see whether consumers are affected by different factors when providing WTP values of pasopati cultivar. Differences in the determination of WTP for chrysanthemums can be used as useful information for producers and flower traders to support decision making in marketing (Rombach et al., 2018).

Previous research on WTP in Indonesia discussed more about food, vegetables and fruit, while research on willingness to pay (WTP) on ornamental plants, especially flowers, is rarely conducted. Short et al. (2017) and Rombach et al.(2018) studies conducted in the United States and Germany each discussed WTP for sunflowers and roses. Previous research conducted by Short et al. (2017) about sunflower WTP 
Agro Ekonomi Vol.32/Issue. 1, June 2021

research conducted in Texas, United States, Rombach et al. (2018) refer to local varieties and measure the ethnicity variable to see the influence on WTP. Research by Rombach et al.(2018) regarding the WTP value of roses in Germany focused on the attributes of fairly traded certification, freshness guarantee and country of origin product. In this study, it is more focused on the social demographic influence and location of consumers on the WTP for chrysanthemum flowers, especially Pasopati cultivar.

Research in Indonesia about the WTP chrysanthemums especially Pasopati cultivar has never been done so far. The purpose of this study are: (1) to find out the characteristics of chrysanthemum consumers in three cities namely Yogyakarta, Semarang and Surakarta, (2) to compare the value of WTP chrysanthemum in three cities, (3) to understand the factors which affects the amount of WTP in each city. The findings of this study have implications for farmers, florists and sellers to improve the production and marketing of chrysanthemum flowers especially for pasopati cultivar, one of unique cultivar from Balithi Indonesia. The result can also guide and promote chrysanthemum flowers to consumers based on potential buying decision.

\section{METHOD \\ Data Collection}

The data was collected through chrysanthemum consumers' surveys in three cities in Central Java Province and Yogyakarta Special Region, i.e., cities of Yogyakarta, Semarang and Surakarta between February and March 2019.
Chrysanthemum flower in this study focused on Pasopati cultivar. This cultivar was developed by Balithi and is widely developed by farmers in the area (Nurmalinda and Hayati, 2014). This cultivar has a bright dark red color that is rarely owned by other cultivars. Nonprobability sampling namely convenience sampling was used to determine respondents with selected criteria from those purchasing chrysanthemum flowers at florists or flower markets in the corresponding cities. Selection criteria of the respondents include those who: 1) knew the appearance of chrysanthemum flowers; and 2) were purchasing chrysanthemum for themselves or for family, and not for resale. There were 120 respondents participated in the surveys, of which 40 respondents in each city. The data used were primary data that obtained from direct interviews with chrysanthemum consumers found at the flower market in each city by using a questionnaire research instrument.

\section{Data Analysis}

To explain the chrysanthemum consumers' characteristics, descriptive analysis of socioeconomic and demographic aspects of the consumers was used. Quantitative research was exerted through the contingent valuation method (CVM) to analyze the WTP of chrysanthemum flowers especially pasopati cultivar and to analyze the determinant factors that influence consumers' WTP used OLS regression.

\section{Willingness to pay of Pasopati Cultivar}


Agro Ekonomi Vol.32/Issue. 1, June 2021

Contingent valuation method was used to analyze the value of WTP for Pasopati cultivar. The Contingent Valuation Method (CVM) was functioned to estimate the economic value of various commodities that do not have prices that are directly visible in the market. The CVM has several stages. These stages include:

1. Create a hypothetical market

The hypothetical market in this study was elaborated based on the potential possessed by chrysanthemums as new cultivar. Respondents were previously asked to listen or read a statement. This statement contained potential and superiority of local cultivar of chrysanthemum flowers, especially Pasopati cultivar that was unique compared to other cultivar.

2. Getting Bid Value

The stage of getting the bid value was done by direct survey to the respondent through a questionnaire to get the maximum value that the respondent wishes to pay Pasopati cultivar. The bid value was obtained by using bidding game technique. The initial value taken in this bidding game was the price of chrysanthemum flower of IDR 30,000 based on the average price of chrysanthemum per ten stalks in Special Region of Yogyakarta and Central Java Province. After that, if the respondent was willing with the price, the price can be increased to the agreed price.

3. Calculate Average WTP value

This value was calculated obtained through the average of the total bid values obtained in the previous stage divided by the number of respondents. The estimated average WTP was calculated using the formula:
$\mathrm{EWTP}=\frac{\sum_{\mathrm{i}=1}^{\mathrm{n}} \mathrm{Wi}}{\mathrm{n}}($ Equation 1$)$

Information :

EWTP : Average value of WTP (IDR)

Wi : WTP value of the respondent $i$ (IDR)

$\mathrm{N}$ : Number of respondents

i $\quad$ : The $\mathrm{i}$-th respondent $(\mathrm{i}=1,2,3, \ldots$ n)

4. Estimating the Bid Curve

The WTP curves of respondents were obtained using the cumulative number of individuals who chose the WTP value. This bid curve connects the value of WTP paid with the cumulative frequency of respondents who are willing to pay additional fees on pasopati cultivar. This curve illustrated the relationship between the level of WTP value and the number of respondents who were willing to pay at that level of WTP.

\section{Aggregating Data}

The data aggregate stage was obtained by converting the average sample obtained in the third stage to the overall population average. The method was to multiply the average sample with the population (respondent). The formula used was as follows:

TWTP = EWTP. Ni (Equation 2)

Information:

TWTP : Total WTP (IDR)

EWTP : Average value of WTP (IDR)

$\mathrm{Ni} \quad$ : Total Population (people)

\section{Determinant Factors of Consumers'} WTP

To analyze the determinant factors of the consumers' WTP, OLS regression analysis was used. Regression was initially carried out with samples in each city then continued with samples from all cities. The models used 
Agro Ekonomi Vol.32/Issue. 1, June 2021

in analyzing regression in each cities are:

$\mathrm{WTP}=\beta_{0}+\beta_{1} \mathrm{AGE}+\beta_{2} \mathrm{EDUC}+\beta_{3} \mathrm{INCM}+$ $\beta_{4} \mathrm{FM}+\beta_{5} \mathrm{PF}+\beta_{6} \mathrm{D}_{1} \mathrm{CP}+\beta_{7}$ $\mathrm{D}_{2} \mathrm{FP}+\beta_{8} \mathrm{D}_{3} \mathrm{GNDR}+$ $\beta_{9} \mathrm{D}_{4} \mathrm{MS}+\beta_{10} \mathrm{D}_{5} \mathrm{ES}+\varepsilon$

(Equation 3)

The dependent variable, 'WTP', was the WTP value of Pasopati chrysanthemum's consumers (in IDR). The independent variables covered both socioeconomic aspects as well as consumers' perception of the Pasopati chrysanthemum flowers. These were: 'AGE' or respondents' age (in years); 'EDUC' or respondents' education level (in years); 'INCM' or respondents' income (in IDR); 'FM' or respondents' family members (in person); 'PC' or respondents' purchase frequencies ( $1=$ never; $2=1-2$ times per month; $3=3-5$ times per month; $4=>5$ times per month); 'CP' or respondents' color perception (1=high; $0=$ low); 'FP' or respondents' freshness perception (1=high; $0=\mathrm{low}$ ); 'GNDR' or respondents' gender $(1=$ female; $0=$ male); 'MS' or respondents' marital status $(1=$ single; $0=$ married); 'ES' or respondents' employment status $(1=$ working fulltime; $0=$ do not work).

To analyze the determinant factors of the consumers' WTP in all cities, OLSregression analysis was employed. The regression model was as follows:

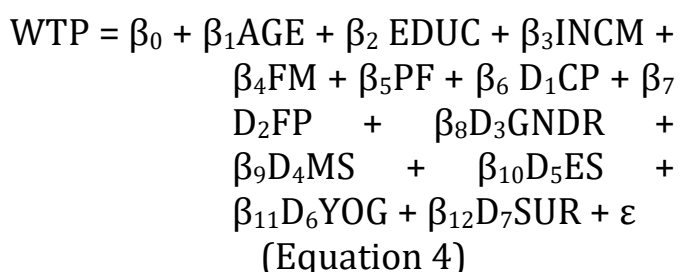

The dependent variable, 'WTP', was the WTP value of Pasopati chrysanthemum's consumers (in IDR). The independent variables covered both socioeconomic aspects as well as consumers' perception of the Pasopati chrysanthemum flowers. These were: 'AGE' or respondents' age (in years); 'EDUC' or respondents' education level (in years); 'INCM' or respondents' income (in IDR); 'FM' or respondents' family members (in person); 'PC' or respondents' purchase frequencies (1= never; $2=1-2$ times per month; $3=3-5$ times per month; $4=>5$ times per month); 'CP' or respondents' color perception (1=high; 0=low); 'FP' or respondents' freshness perception (1=high; $0=$ low); 'GNDR' or respondents' gender ( $1=$ female; $0=$ male); 'MS' or respondents' marital status (1= single; $0=$ married); 'ES' or respondents' employment status ( $1=$ working fulltime; $0=$ do not work); 'YOG' or dummy Yogyakarta (1= Yogyakarta City; $0=$ Other city); 'SUR' or dummy Surakarta (1= Surakarta City; $0=$ Other city).Normality, multicollinearity, heteroscedasticity, and autocorrelation tests were also conducted, and the model fulfilled those classical assumptions.

\section{RESULTS AND DISCUSSION}

Characteristics of Chrysanthemum Consumer in Yogyakarta, Semarang and Surakarta

Each city has different chrysanthemum consumer characteristics. From 120 respondents, the majority of consumers in the cities of Yogyakarta, Semarang and Surakarta are 17-25 years old (Table 1). 


\section{Agro Ekonomi Vol.32/Issue.1, June 2021}

Chrysanthemum flower consumers were mostly women with a percentage reaching 75 percent, hold bachelor degree education level and single. In their research, Huang and Yeh (2009) showed that consumers of flower products were mostly women and had a high level of education. In accordance with employment status, the majority of consumers in the city of Yogyakarta had no job; while respondents in Semarang and Surakarta were dominantly workers. Consumers having no job in Yogyakarta were mainly university

Table 1. Characteristics of Chrysanthemum Consumers in Yogyakarta, Semarang, and Surakarta

\begin{tabular}{lllll}
\hline Characteristics & $\begin{array}{l}\text { Yogyakart } \\
\mathrm{a}(\%)\end{array}$ & $\begin{array}{l}\text { Semarang } \\
(\%)\end{array}$ & $\begin{array}{l}\text { Surakarta } \\
(\%)\end{array}$ & $\begin{array}{l}\text { All cities } \\
(\%)\end{array}$ \\
\hline Age & & & & \\
$17-25$ & 65 & 60 & 40 & 55 \\
$26-35$ & 30 & 25 & 32.5 & 29 \\
$36-45$ & 2.5 & 5 & 17.5 & 9 \\
$46-55$ & 2.5 & 7.5 & 2.5 & 4 \\
$55-65$ & 0 & 2.5 & 7.5 & 3 \\
Gender & & & & \\
Women & 85 & 72,5 & 67,5 & 75 \\
Men & 15 & 27,5 & 32,5 & 25 \\
Latest education level & & & & \\
Junior high school & 5 & 2.5 & 7.5 & 5 \\
High school & 25 & 17.5 & 12.5 & 18.3 \\
Diploma & 7.5 & 10 & 12.5 & 10 \\
S1 & 47.5 & 57.5 & 42.5 & 49.1 \\
S2 & 15 & 12.5 & 25 & 17.5 \\
Employment Status & & & & \\
Working full-time & 42.5 & 65 & 62.5 & 56.7 \\
Do not work & 57.5 & 35 & 37.5 & 43.3 \\
Marital Status & & & & \\
Married & 22.5 & 35 & 52.5 & 36.7 \\
Single & 77.5 & 65 & 47.5 & 63.3 \\
Number of family & & & & \\
members/dependents & & & & \\
0 & 60 & 67.5 & 52.5 & 60 \\
1 & 12.5 & 5 & 15 & 10.8 \\
2 & 12.5 & 12.5 & 20 & 15 \\
3 & 10 & 7.5 & 5 & 7.5 \\
4 & 5 & 5 & 5 & 5 \\
5 & 0 & 2.5 & 2.5 & 1.7 \\
\hline
\end{tabular}

Source: Primary data (2019)

Research conducted by Wijayani et chrysanthemum in Special Region of al. (2017) shows that consumers of Yogyakarta and Central Java were students, as commonly found in this city for its title as city of students in Indonesia.

In relation to that, consumers in Yogyakarta were mostly single with no dependent. This was a contrast with consumers are mostly married. Several previous studies related to the behavior of consumers of the flower market show that the majority of respondents were in their 20 s to 50 s. Semarang and Surakarta where 


\section{Agro Ekonomi Vol.32/Issue.1, June 2021}

dominated by workers because they usually bought cut flowers for formal events such as seminars, workshops, training and others.

\section{Willingness to Pay of Pasopati Chrysanthemum Consumers}

The WTP of Pasopati chrysanthemum consumers was varied across the three studied cities. In terms of maximum WTP, Semarang respondents, which maximum WTP was IDR 65,000 per ten stalks of flowers, value the chrysanthemum flower the highest among the other cities (Table 2). Of the minimum WTP, it was found in Surakarta, where ten stalks of chrysanthemum were valued by only IDR 10,000. On average, Semarang also had the highest average WTP among the other cities, i.e., IDR 38,750, followed by Surakarta with IDR 38,125, and then Yogyakarta with the lowest WTP of IDR 37,000 . Semarang city's minimum wage, which was higher compared to Yogyakarta and Surakarta cities (BPS of Central Java Province, 2019), contributed to this. This is in line with the research of Romano et al., (2016), that the higher the income, the higher the value of the consumers' WTP.

The average WTP of all respondents in the three cities was IDR 37,958 . The average WTP value in the three cities was higher than the market price for a bunch of chrysanthemums of IDR 30,000 . This was due to the fact that consumers considered chrysanthemum flowers, especially cultivar pasopati to have unique flowers and was also the result of domestic inventions so that consumers wanted to buy these flowers at higher prices. According to Short et al., (2017) consumers are willing to pay more for products labeled locally.

The bid curve of consumers' WTP correlates between the value of consumers' WTP for Pasopati cultivar and cumulative frequencies. The higher value of WTP will result in smaller number of individuals who are willing to pay (Mankiw, 2008). Figure 1 explains the relationship between the value of WTP and the number of respondents who are willing to pay. As a result, the higher value of WTP, the fewer consumers were willing to pay.

Table 2. WTP of Pasopati Chrysanthemum Consumers in Yogyakarta, Semarang and Surakarta

\begin{tabular}{lllll}
\hline Criteria & $\begin{array}{l}\text { Yogyakarta } \\
\text { (IDR) }\end{array}$ & $\begin{array}{l}\text { Semarang } \\
\text { (IDR) }\end{array}$ & $\begin{array}{l}\text { Surakarta } \\
\text { (IDR) }\end{array}$ & All cities (IDR) \\
\hline Maximum WTP value & 55,000 & 65,000 & 55,000 & 65,000 \\
Minimum WTP value & 20,000 & 20,000 & 10,000 & 10,000 \\
Average WTP values & 37,000 & 38,750 & 38,125 & $37,958.33$ \\
\hline
\end{tabular}

Source: Primary data (2019) 
Agro Ekonomi Vol.32/Issue. 1, June 2021

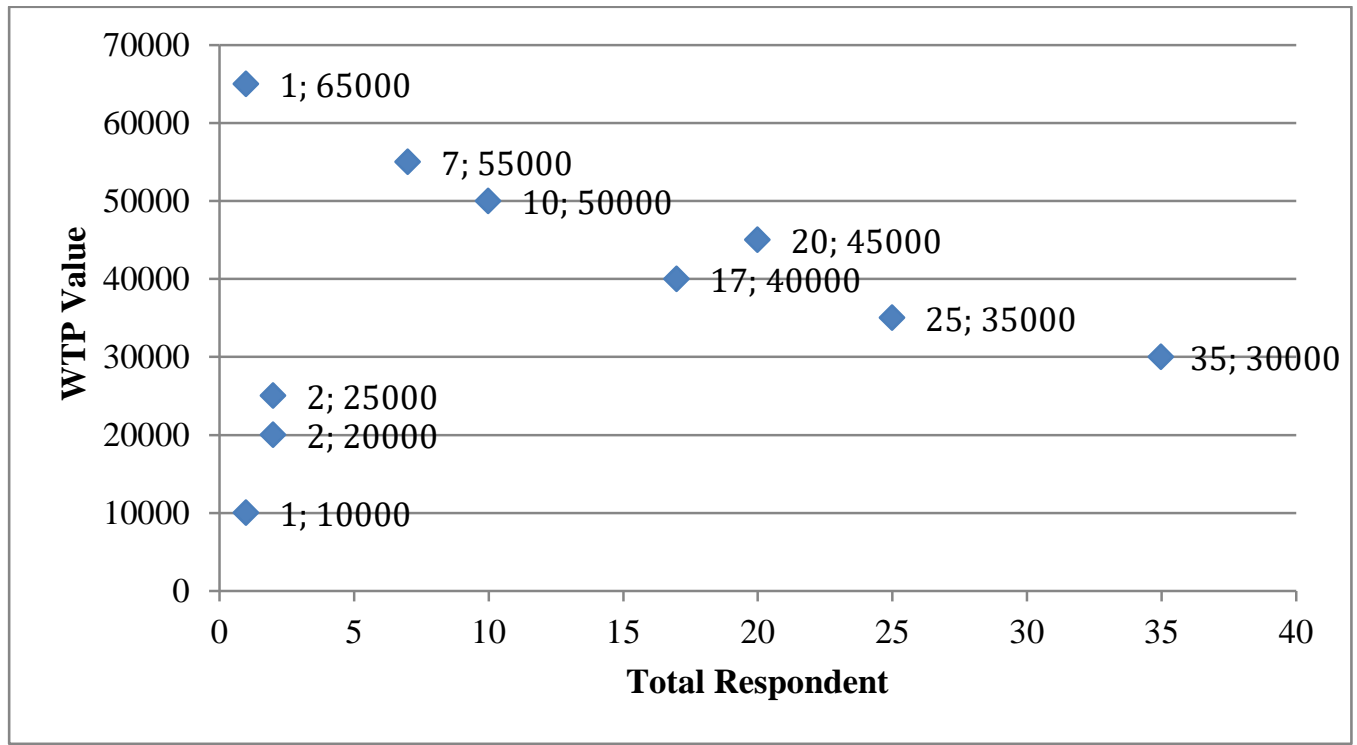

Figure 1. Bid Curve of Pasopati Cultivar WTP

The final stage of the CVM method was to aggregate the sample average data by multiplying the sample mean with the population size. It is known that the average value of WTP in three cities was $37,958.33$ with the total population in three cities namely Yogyakarta City, Semarang City and Surakarta City amounting to $2,696,520$ people. So, the total WTP for the Pasopati cultivar chrysanthemum flowers amounting to IDR 102,355,396,012. According to Priambodo (2013), the total WTP could be used as an information related to financial potential in an area from the presence of chrysanthemums of local varieties, mainly Pasopati cultivar.

Determinants Factors of Pasopati Chrysanthemum Consumers' Willingness to Pay

Regression of WTP value of Yogyakarta City indicate that 44.2 percent of the variation of the dependent variable could be explained by independent variables in the model. Factors that significantly influenced the WTP value of Pasopati chrysanthemum consumers in Yogyakarta City were age and income. Meanwhile, the WTP value of Pasopati chrysanthemum in Semarang City could be explained by the variation of independent variable in the model by 58.7 percent. Age, income, and color perception were factors that influence the WTP. WTP regression model of Surakarta showed that the variation of the dependent variable explained by the independent variable was 64.1 percent. Factors that significantly influenced the value of WTP were the level of education, income, marital status, and employment status (Table 3). Results of regression of factors that affected the value of WTP can be seen in Table 3 . 
Agro Ekonomi Vol.32/Issue. 1, June 2021

Table 3. Determinant Factors Of Consumers WTP Chrysanthemum Flower Pasopati Cultivar

\begin{tabular}{|c|c|c|c|c|c|c|c|c|c|}
\hline Variable & $\begin{array}{l}\text { Expecte } \\
\text { d sign }\end{array}$ & $\begin{array}{l}\text { RegressionC } \\
\text { oeffisients( } \\
\text { YOG) }\end{array}$ & p-value & $\begin{array}{c}\text { Regression } \\
\text { Coeffisient } \\
\text { s (SMG) }\end{array}$ & p-value & $\begin{array}{c}\text { Regression } \\
\text { Coeffisient } \\
\text { s (SUR) }\end{array}$ & p-value & $\begin{array}{l}\text { Regression } \\
\text { Coeffisients } \\
\text { (All) }\end{array}$ & $\mathrm{p}$-value \\
\hline Constanta & + & $\underset{n s}{15,233.267}$ & 0.296 & $23,996.455 \mathrm{~ns}$ & 0.197 & $12,536.409 \mathrm{~ns}$ & 0.242 & $8,036.334 \mathrm{~ns}$ & 0.198 \\
\hline Age & + & $618.730^{* * *}$ & 0.009 & 525.711 & 0.006 & 143.257 ns & 0.228 & $366.606^{* * *}$ & 0.000 \\
\hline $\begin{array}{c}\text { Educational } \\
\text { level }\end{array}$ & + & $-194.446^{n s}$ & 0.742 & $700.065^{\mathrm{ns}}$ & 0.259 & $868.408^{*}$ & 0.054 & $854.556^{* * *}$ & 0.001 \\
\hline Income & + & $0.003^{* * *}$ & 0.004 & $0.002^{* * *}$ & 0.003 & $0.003^{* * *}$ & 0,000 & $0.002^{* * *}$ & 0.000 \\
\hline $\begin{array}{l}\text { Family } \\
\text { Member } \\
\text { s }\end{array}$ & - & $\begin{array}{c}-335.76 \\
\text { ns }\end{array}$ & 0.703 & $-1120.936^{\mathrm{ns}}$ & 0.191 & $-923.340^{\mathrm{ns}}$ & 0.210 & $-652.073^{\mathrm{ns}}$ & 0.129 \\
\hline $\begin{array}{l}\text { Purchase } \\
\text { frequency }\end{array}$ & - & $\begin{array}{c}-2,449.879 \\
n s\end{array}$ & 0.325 & $-4,054.371^{\mathrm{ns}}$ & 0.411 & 915.354 ns & 0.738 & -206.189 ns & 0.886 \\
\hline $\begin{array}{c}\text { Color } \\
\text { perceptio } \\
n\end{array}$ & + & $\begin{array}{c}-2,449.879 \\
n s\end{array}$ & 0.930 & $6,035.096^{*}$ & 0.094 & $3,741.551^{\mathrm{ns}}$ & 0.321 & $4,151 \cdot 137^{* * *}$ & 0.044 \\
\hline $\begin{array}{l}\text { Freshness } \\
\text { perception }\end{array}$ & + & $-583.588 \mathrm{~ns}$ & 0.513 & $-11,674.066^{\mathrm{ns}}$ & 0.229 & $-33.126^{\mathrm{ns}}$ & 0.995 & $-910.235^{\mathrm{ns}}$ & 0.242 \\
\hline Gender & + & $5,402 \cdot 144 \mathrm{~ns}$ & 0.122 & $-1,607.023$ ns & 0.548 & $-422.459 \mathrm{~ns}$ & 0.878 & $1,132.281 \mathrm{~ns}$ & 0.432 \\
\hline $\begin{array}{l}\text { Marital } \\
\text { Status }\end{array}$ & + & $4,150.832^{\mathrm{ns}}$ & 0.236 & $49.496^{\mathrm{ns}}$ & 0.986 & $-4,110.344^{*}$ & 0.095 & $\begin{array}{c}-1,352.287 \\
n s\end{array}$ & 0.361 \\
\hline $\begin{array}{c}\text { Employmen } \\
\text { t Status }\end{array}$ & + & $2,624.530^{\mathrm{ns}}$ & 0.392 & $2,018.699$ ns & 0.471 & $-5,145.122^{* *}$ & 0.037 & $-298.046^{\mathrm{ns}}$ & 0.821 \\
\hline $\begin{array}{c}\text { Yogyakarta } \\
\text { (location) }\end{array}$ & - & & & & & & & $\begin{array}{c}616.725^{\mathrm{n}} \\
\mathrm{s}\end{array}$ & 0.650 \\
\hline $\begin{array}{l}\text { Surakarta } \\
\text { (location) }\end{array}$ & - & & & & & & & $\begin{array}{c}- \\
2,929.486^{* *}\end{array}$ & 0.031 \\
\hline \multicolumn{2}{|c|}{ F-Statistic } & \multicolumn{2}{|c|}{$4.091^{* * *}$} & \multicolumn{2}{|c|}{$6.535^{* * *}$} & \multicolumn{2}{|c|}{$7.967^{* * *}$} & \multicolumn{2}{|c|}{$14.701^{* * *}$} \\
\hline \multicolumn{2}{|l|}{ Adj R ${ }^{2}$} & \multicolumn{2}{|c|}{0.442} & \multicolumn{2}{|c|}{0.587} & \multicolumn{2}{|c|}{0.641} & \multicolumn{2}{|c|}{0.580} \\
\hline
\end{tabular}

YOG: Yogyakarta; SMG: Semarang; SUR: Surakarta

***: significant at $\alpha=1 \%$; ${ }^{* *} \quad$ : significant at $\alpha=5 \%$; $^{*} \quad$ : significant at $\alpha=10 \%$; ns: insignificant

\section{Yogyakarta City}

Increase in the respondent's age by 1 year will increase the WTP value of Pasopati chrysanthemum by IDR 618.730. Consumers in the city of Yogyakarta were dominated by young people. According to Huang and Yeh (2009), age influenced consumers in choosing flowers. Young people chose flowers based on their first impression of beauty while older people considered the price to choose flowers. Regression results also show that an increase in income by one unit (IDR) will increase the value of WTP by IDR 0.003 . According to Zhang et al., (2018), an increase in consumer income will increase the value of consumer WTP on a product.

\section{Semarang City}

A one-year increase in age will increase the value of WTP by IDR 525.711 and an additional income of IDR 1 will increase the value of WTP by 0.002. Consumers having high color perception, have a higher WTP value of IDR 6,035.096. Consumers in the city of Semarang put color into consideration when making decision in the appropriate price of the Pasopati chrysanthemum. According to Nurmalinda and Hayati (2014), color is comprised in the attributes of flowers that consumers pay attention to when 


\section{Agro Ekonomi Vol.32/Issue.1, June 2021}

making a purchase, besides size, shape, rigidity and vase life. The flowers' color selection usually follows occasions, such as weddings, religious events, or other holiday celebrations.

\section{Surakarta City}

Every increase in one year of education, the WTP value of chrysanthemums increased by IDR 868.408. An increase in income of IDR 1 will increase the value of WTP by IDR 0.003 . These results are the same as the Yogyakarta. Single consumers had a different WTP value of IDR 4,110.344, lower than married consumers, indicating that married consumers were willing to pay more for chrysanthemum flowers. Different result shown at Surakarta. Consumers who had been employed had a lower WTP value of IDR $5,145.12$, indicating they were willing to pay more for flowers. Several previous studies have shown that there is a relationship between consumer spending to buy fresh flowers with socio-demographic characteristics such as marital status and employment status (Schimmenti et al., 2013; MayettMoreno et al., 2018).

\section{All Cities}

Overall, variations in the value of WTP in three cities in Java, namely Yogyakarta City, Semarang City and Surakarta City could be explained by variables of age, level of education, income, number of family members, frequency of purchase, color perception, perception of resilience, gender, marital status, employment status, and dummy location of Surakarta by 58 percent. The remaining 42 percent was explained by other variables outside the model. Variables having a significant effect on the value of WTP in three cities were age, level of education, income, color perception and location of Surakarta.

Every one year increase in age, the WTP value of chrysanthemums will increase by IDR 366.606 . These results were consistent with research conducted by (Schimmenti et al., 2013) that age has a positive relationship in flower purchasing decisions, someone that have older age will be more interested and willing to buy flowers. Similar with level of education. Every 1 year increase in education, the value of WTP will increase by IDR 854.556. In addition to education, income also influenced the WTP value of chrysanthemum of cultivar pasopati. If there is an increase of IDR 1 in income, the WTP value of chrysanthemum flowers cultivar pasopati will increase by IDR 0.002 . According to Yue and Hall (2010), demographic characteristics such as education and income are factors that play a role in the purchase of flowers. Consumers with high color perception had higher WTP value of IDR 4,151.137 compared to having lower color perception. Flower color has its own meaning and symbol so that it is an important attribute (Yue and Behe, 2010).

The difference in the value of WTP was also influenced by the location of the purchase. Consumers in the city of Surakarta had a lower WTP value of IDR 2,929.448. Residents in the city of Surakarta often use chrysanthemums for events such as weddings, religious events and events in Javanese culture. But in economic terms, Surakarta City when compared to Semarang City had a smaller regional minimum wage value 
Agro Ekonomi Vol.32/Issue.1, June 2021

so the purchasing power for chrysanthemum was also smaller than Semarang City.

\section{CONCLUSIONS AND SUGGESTIONS}

The majority of chrysanthemum consumers in the cities of Yogyakarta, Semarang and Surakarta were 17-25 years old, are female, had a bachelor's education, and did not have family members covered. The work status of the majority of consumers in Semarang City and Surakarta City was on-working, while in Yogyakarta City did not / had not worked. The marital status of consumers in Yogyakarta City and Semarang City was majority single, while in Surakarta City the majority was married. The average value of WTP for chrysanthemums of cultivar pasopati obtained was IDR 37,958.33 per one bunch of flowers or 10 stalks. This price is higher than the market price of IDR 30,000. Yogyakarta had an average WTP value of IDR 37,000. Semarang City had an average WTP value of IDR 38,750 and Surakarta City had an average WTP value of IDR 38,125 for 10 chrysanthemum flower cultivar pasopati stalks. Factors influencing consumer WTP value of chrysanthemum cultivar pasopati were different in each city. The factors that significantly influencing were age and income in Yogyakarta, while in Semarang are age, income and color perception, in Surakarta were education level, income, marital status and employment status. Meanwhile, when viewed as a whole from the three cities, several factors such as age, level of education, income, color perception and location of Surakarta had a significant influence on the WTP value.
The WTP value of chrysanthemum flowers especially cultivar pasopati can be used as a reference to determine the selling price of chrysanthemum flowers. The development of chrysanthemums of local cultivar such as pasopati, needs to be developed more by looking at the willingness of consumers to pay. Farmers and florist can introduce chrysanthemum cultivar pasopati to consumers of mature age, and have high education and income. Farmers and flower sellers also need to implement a marketing mix strategy in the chrysanthemum flower market by considering the social and demographic aspects of consumers.

\section{REFERENCES}

Badan Litbang Pertanian (2016) 'Varietas Pasopati'. Available at: http://www.litbang.pertani an.go.id/varietas/one/715/.

Badan Pusat Statistik (2018) Statistik Tanaman Hias 2017. Jakarta.

Badan Pusat Statistik (2019) Statistik Tanaman Hias Indonesia.

Badan Pusat Statistik Jawa Tengah (2019) Kebutuhan Hidup Layak dan Upah Minimum Kabupaten/Kota Menurut Kabupaten/Kota di Provinsi Jawa Tengah, 2017-2019. Available at: https://jateng.bps.go.id/dyn amictable/2019/12/17/646 /kebutuhan-hidup-layakdan-upah-minimumkabupaten-kota-menurutkabupaten-kota-di-provinsijawa-tengah-2017-2019.html (Accessed: 9 January 2020).

Briercliffe, T. (2017) 'Growing the global market for ornamentals', Acta Horticulturae, 1165, pp. 1-8. doi: 
Agro Ekonomi Vol.32/Issue.1, June 2021

10.17660/ActaHortic.2017. 1165.1 .

Datta, S. K. (2018) 'Breeding of new ornamental varieties: Rose', Current Science, 114(6), pp. 1194-1206. doi: $10.18520 / \mathrm{cs} / \mathrm{v} 114 / \mathrm{i} 06 / 119$ 4-1206.

Huang, L. C. and Yeh, T. F. (2009) 'Floral consumption values for consumer groups with different purchase choices for flowers', HortTechnology, 19(3), pp. 563-571. doi: 10.21273/hortsci.19.3.563.

Mayett-Moreno, Y. et al. (2018) 'Consumers' and retailers' attitudes towards a Mexican native species of Aztec Lily as an ornamental plant', Sustainability (Switzerland), 10(1). doi: $10.3390 /$ su10010224.

Nurmalinda and Hayati (2014) 'Preferensi Konsumen Terhadap Krisan Bunga Potong dan Pot ( Consumer Preferences

Chrysanthemum Cut Flowers and Pot )', Journal Hortikultura, 24(4), pp. 363-372. doi http://dx.doi.org/10.21082 /jhort.v24n4.2014.p363372.

Pusat Data dan Informasi Kementerian Pertanian (2014) Outlook Komoditi Krisan. Jakarta.

Romano, K. R. et al. (2016) 'Willingness to pay more for value-added pomegranate juice (Punica granatum L.): An openended contingent valuation', Food Research International. Elsevier Ltd, 89, pp. 359364.

doi: 10.1016/j.foodres.2016.08.0 39.
Rombach, M. et al. (2018) 'Do all roses smell equally sweet? Willingness to pay for flower attributes in specialized retail settings by German consumers', Journal of Retailing and Consumer Services, 40(July 2017), pp. 91-99. doi: 10.1016/j.jretconser.2017.0 9.007.

Sanjaya, L., Marwoto, B. and Soehendi, R. (2015) 'Membangun industri bunga krisan yang berdaya saing melalui pemuliaan mutasi', Pengembangan Inovasi Pertanian, 8(1), pp. 43-54.

Schimmenti, E. et al. (2013) 'Behaviour of consumers of conventional and organic flowers and ornamental plants in Italy', Horticultural Science, 40(4), pp. 162-171. doi: $\quad 10.17221 / 115 / 2013-$ hortsci.

Short, K., Etheredge, C. L. and Waliczek, T. M. (2017) 'Studying the market potential for specialty cultivars of sunflower cut flowers', HortTechnology, 27(5), pp. 611-617. doi: 10.21273/HORTTECH0371 0-17.

Wijayani, A., Muafi and Sukwadi, R. (2017) 'Market actor's response towards flower colours in determining the economic value of Chrysanthemum flowers', Journal of Business and Retail Management Research, 12(1), pp. 69-75. doi: 10.24052/jbrmr/v12is01/ martfcidtevocf.

Yue, C. (2008) 'Estimating U . S . Consumers ' Choice of Floral 
Agro Ekonomi Vol.32/Issue.1, June 2021

Retail Outlets', (June 2014).

doi:

10.21273/HORTSCI.43.3.76

4.

Yue, C. and Behe, B. K. (2010) 'Consumer color preferences for singlestem cut flowers on calendar holidays and noncalendar occasions', HortScience, 45(1), pp. 7882.

doi: 10.21273/hortsci.45.1.78.

Yue, C. and Hall, C. (2010) 'Traditional or specialty cut flowers? Estimating U.S. consumers' choice of cut flowers at noncalendar occasions', HortScience, 45(3), pp. 382386.

doi: 10.21273/hortsci.45.3.382.

Zhang, B. et al. (2018) 'Consumers' perceptions, purchase intention, and willingness to pay a premium price for safe vegetables: A case study of Beijing, China', Journal of Cleaner Production. Elsevier Ltd, 197, pp. 1498-1507. doi:

10.1016/j.jclepro.2018.06.2 73. 